\title{
人工膜による分子認識
}

自励発振現象の応用

\author{
吉 川 研 - \\ 徳島大学教養部 $\overline{\mathbf{T}} 770$ 徳島市南常三島 $1-1$
}

\section{Recognition of Various Chemical Species by Artificial Membranes as an Application of Self-Excitable Phenomenon}

\section{Kenichi Yoshikawa}

College of General Education, University of Tokushima, Minami-josanjima, Tokushima 770

\begin{abstract}
In living organisms, recognition of molecules, such as by taste, smell or immunity, is essential for the maintenance of life. It is well known that the excitability of the bio-membranes is quite important to recognize various chemicals. The development of excitable artificial membranes is thus important to understand the mechanism of molecular recognition in biological systems. In this article, the history of studies of artificial membranes excitable by electrical current, voltage, hydrostatic or osmotic pressure, and chemical substances are reviewed. Among these studies, the work by the author and his collaborators shows that excitable phenomenon is applicable to the recognition of various chemical species. The development of a new type of chemical sensor capable of distinguishing chemical substances on the basis of information on the frequency, amplitude and the shapes of electrical pulses is suggested to be promising.
\end{abstract}

Key words: Oscillation, Membrane potential, Taste, Olfaction, Lipid membrane, Sensor

\section{1. はじめに}

生体系では, 細胞膜が各種の情報変換機能を担ってい る. 視覚では, 光刺激が, 神経の電気的インパルスに変 換されている，触覚では，熱・圧力などの物理的刺激が, 神経インパルスに変換され, 味覚・嗅覚では, 化学的情 報が神経の電気的パルスとなる。すなわち, 生体膜を介 して, 物理的・化学的情報が神経の電気信号となること が外的情報の認識のために必須の過程となっている.

味覚・嗅覚では, 味細胞・嗅細胞の細胞膜が外部から の化学的刺激を受容し, 受容細胞につながる神経細胞に 電気的信号 (電位のパルス的変動) が発生する ${ }^{1}{ }^{*}$ この 神経細胞の電気的興奮が中枢に伝えられることによって,

* 味覚では, 受容細胞と神経細胞とは別の細胞であるが, 嗅細胞で は,受容細胞自体から神経のインパルスがでるてとがわかっている。
生体は，化学的情報を認識・識別することが出来ている わけである (Fig. 1参照).

一方, 従来からの化学センサー ( $\mathrm{pH}$ 電極など) では, 化学的情報は, 膜の直流電圧（クラーク型酸素電極なと では, 直流電流) に変換される (Fig. 2). このため, 原 理的に, 一個のセンサーでは単一の物質を検出・定量で きるだけあり, 共存物は常に邪魔物・妨害物となる。そ こで，単一の物質に対する選択性を高めることが極めて 重要である. 水素イオンや, 無機イオンに関しては, 高 い選択性をむつ電極が, 既に得られているが, 有機物質 となると, 極めて多種多様なものが存在するため有機物 質を直流電压 (電流) でもって識別する電極をつくるこ とは，はなはだ困難になる，選択性を高める目的で，酵 素電極やオルガネラ (細胞顆粒) センサー等が開発され てきており，面白い結果も得られている．しかしながら， 


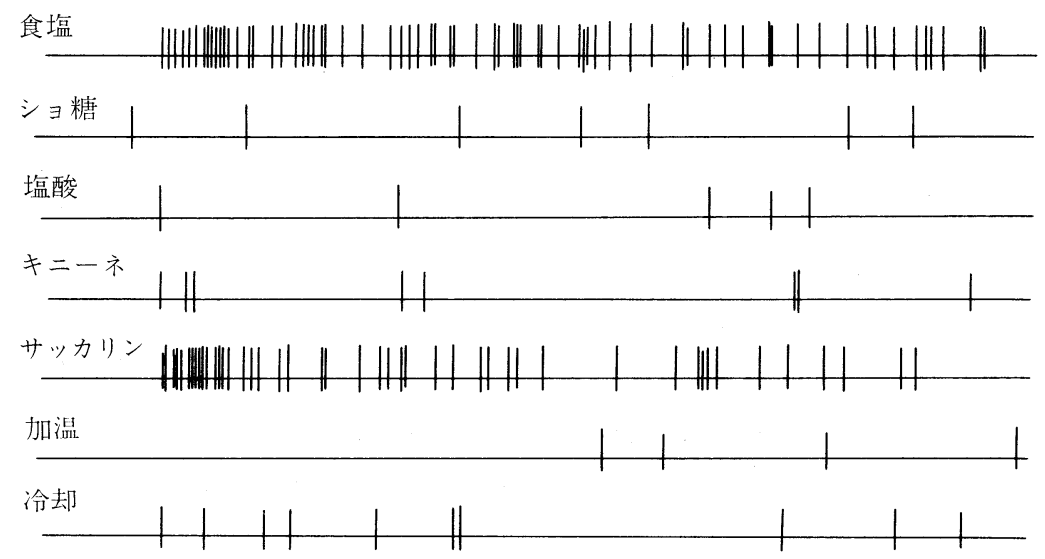

無刺激

Fig. 1 ラット味細胞に対する化学刺激の電気的応答 ${ }^{2)}$ 1 秒 味細胞に接続する神経細胞の電位が, パルス的に変化していることを示している （単一の神経細胞に対しての測定）

従来の化学センサー

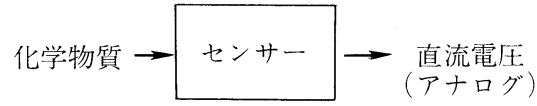

味覚・嗅覚

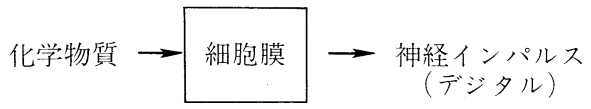

Fig. 2 従来の化学センサーと, 味覚・嗅覚におけ る情報変換の比較

多様な有機物に，感応し，識別できる人工センサーの開 発のためには，全く異なった視点からのアプローチがあ ってもよいのではないだろうか.

ここで, 味覚・嗅覚では, 細胞膜の興奮性が重要な役 割を果たしていることに注目したい. Fig.1からも判る ように, 生体膜では, デジタル的な電気信号一すなわ ち, 膜の電気的興奮—でもって，化学情報を識別して いる. 単一の味細胞が, 単一の化学物質にだけ応答して いるわけでは決してない。 パルスの頻度やパターンの中 に, 種々の化学的情報（濃度や化学構造）が含まれてい る．味覚・嗅覚の分子論に関しては未だ定説がなく，不 明な点が多い。しかし，デジタル的なインパルスの頻度 やパターンでもって, 多種類の化学物質を検出・定量し ていることは，間違いのないところであろう。

そこで, 生体におけるこのような分子認識の機構を学 ぶ立場に立てば，膜の興奮性に注目することが重要とな
る. 本稿では, まず, よ゙のような人工膜が興奮性を示す のか, といった点について述べる. 次に, このような興奮 性膜が，各種の化学物質に対し，どのような応答性を示 すのか, といった事を，私共の最近の研究結果を中心に して, 紹介したい.

\section{2. 人工膜における発振現象}

フランス革命の 2 年後 1791 年に, カエルの筋肉が, 金 属片によって急激に収縮するてとを Galvaniが発見して 以来, 生体の電気的興奮現象は, 生理学・生命科学の中 心課題の一つとなった。実際に, 多くの研究者が, 人工 膜系で興奮・発振現象を再現しようと試みてきた。

Table 1 には, 現在迄に知られている, 人工膜系の発 振現象を示した。古くは, 1950 年代に, Teorellの発見 した, ガラスフィルターでの電気的発振がある ${ }^{3,4)}$. す なわちガラスフィルターで, 左右の水層を仕切り, 両水 層間に適当な静水圧と電圧差をかけ，さらに塩の濃度差 をつけ加えると電気的な発振が生じる，といったもので ある。乙の発見は，タンパクなどの複雑な構造の生体物 質が全く存在しない条件でも，膜が発振することを示し たものとして画期的であった。 あち万ん，水溶液の全く 存在しない dry な電気回路での発振現象は, はるか昔か ら知られてはいたが, 水溶液に仕切られた膜での発振之 しては，てれがおそらく最初であろう. Teorell の発見 以降，ガラスフィルター以外にも，多孔性のプラスチッ ク・フィルターやイオン交換膜を用いても, 水圧・電圧・ 
Table 1 人工膜における発振現象

\begin{tabular}{|c|c|c|c|}
\hline 膜 & 発振波形 & 駆動力 & 研究者(年) \\
\hline $\begin{array}{l}\text { リン脂質二分子膜 } \\
+\operatorname{EIM}(\text { タンパク })\end{array}$ & 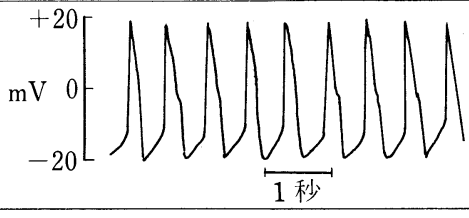 & 直流電流 & $\begin{array}{l}\text { Mueller \& } \\
\text { Rudin }^{14,15)} \\
(1967)\end{array}$ \\
\hline ガラスフィルター & UU $\underbrace{}_{30 \text { 分 }} \Omega U$ & $\begin{array}{l}\text { 静 水 圧 } \\
\text { 直流電流 } \\
(25 \mathrm{~mA})\end{array}$ & $\begin{array}{l}\text { Teorell } \\
(1958)\end{array}$ \\
\hline イオン交換膜 & $0.1 \mathrm{~V}[\mathrm{~N}$ & 直流電流 & $\begin{array}{l}\text { 山木啓太 }^{7)} \\
{ }^{7961)} \\
\text { Shashoua }^{9)} \\
(1967)\end{array}$ \\
\hline $\begin{array}{l}\text { 乾 性 油 膜 } \\
\text { (酸化重合) }\end{array}$ & 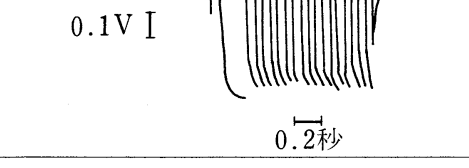 & 直流電流 & $\begin{array}{l}\text { Monnier }^{11,12)} \\
(1964)\end{array}$ \\
\hline $\begin{array}{l}\text { 脂質DOPHを含浸 } \\
\text { させたミリボア膜 }\end{array}$ & $20 \mathrm{mV}\lceil$ & 直流電流 & $\begin{array}{l}\text { 小 } \text { 唣 }^{19,20)} \\
(1970)\end{array}$ \\
\hline $\begin{array}{c}\text { リン脂質二分子膜 } \\
\text { (黒膜) }\end{array}$ & $10 \mathrm{mVI}$ Wruphwhww & $\begin{array}{c}\text { 化学反応 } \\
\text { 左側水層; } \\
\quad \mathrm{K} 1, \mathrm{pH} 10 \\
\text { 右側 水層; } \\
\mathrm{Fe}(\mathrm{CN})_{6}^{3+}, \mathrm{pH} 5\end{array}$ & $\begin{array}{l}\text { Pant \& } \\
\text { Rosenberg 24) } \\
\quad(1971)\end{array}$ \\
\hline
\end{tabular}

塩濃度差の 3 つのパラメータを適当に設定してやると, 電気的な興奮が生じることが見出されている ${ }^{5 \sim 10)}$.

生体膜の二分子膜構造は, 脂質分子が平面状に配向す るととによってできている，それゆえ，脂質を用いた興 奮性膜の研究が重要となる. 脂質からなる人工膜で, 発 振を生じさせることに最初に成功したのは, フランスの 生理学者 Monnier である ${ }^{11 \sim 13)}$. その後, Mueller と Rudin は, リン脂質二分子膜 (黒膜) 系での電気的発振 を報告した ${ }^{14,15)}$ 。乙れは, 腸内細菌の一種, Enterobacter cloacae fecalis から抽出した, タンパク質 （RNA む含む複合体）を，リン脂質二分子膜に埋め込み， 外部から直流電圧を印加すると, 電気的発振が生じる, といったものである. 彼らは, このタンパク様物質を,
E. I.M. (Excitability induced material, 興奮性誘起物 質）之称している. 近年になって, EIM 以外にも, 電気 ウナギの電気器管より精製したアセチルコリン・レセプ ターや, Na/K ATP 加水分解酵素など, 様々なタンパ ク質を埋め込んだ，リン脂質二分子膜が，電気的興奮や 発振現象を示すことがわかってきている ${ }^{16 \sim 18)}$.

このような流れとは別に, 北海道大学の小畠は, ジオ レイルホスフェイトを含浸させた, ミリポア膜に, 塩濃 度差と直流電流を印加すると, 電気的発振が生じること を発見している ${ }^{19,20)}$. 乙の系の研究は, その後, 有沢 ${ }^{211}$, 都甲 ${ }^{22}{ }^{23)}$ らにより発展している. これは, タンパク質 の無い, 脂質分子だけでできた膜が，興奮現象を示すこ とを明らかにしたものとして, 重要である ${ }^{24,26)}$. 


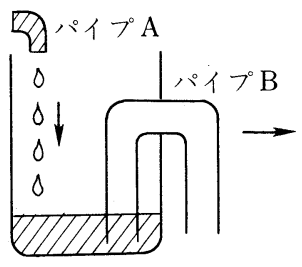

(1) 水がたまっていく

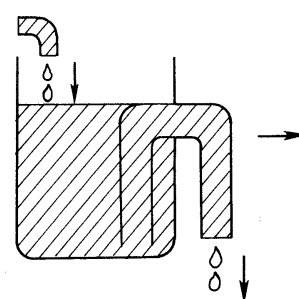

(2) 水が外に出始める (スイッ千開)

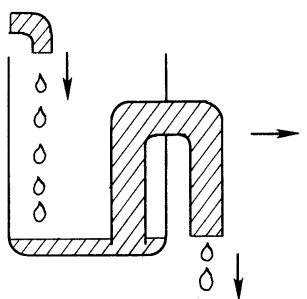

(3) 水が外に出切る (スイッ千閉)

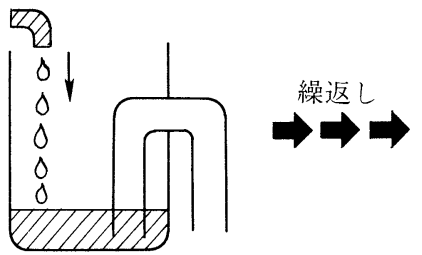

(4)再び水がたまる

Fig. 3 なぜ発振 (リズム) が生じるか ${ }^{28)}$ (パイプAからの流れは一定であるにあかかわらず，パイプBからの流机は周期的となる)

\section{3. 発振（リズム）の生じる条件は?}

化学的な振動現象としては, 1958年に発見された, Belousov-Zhabotinskii 反応が有名である ${ }^{27,28)}$ 。乙れ は, マロン酸などの有機酸を, 金属触媒存在下, 臭素酸 酸化するときに，周期的な酸化・還元反応を引きおこす あのである. この反応の研究が, 近年盛んにおてなわれ， さらに非線形非平衡熱力学の理論の発展が相伴うことに よって, 化学的な振動の発生するための条件す, 次第に 明らかになってきている。

Fig. 3 には, どての化学実験室にああるような, ピペ ット洗浄器に打ける, 水の流れの, 周期的変化を示した ${ }^{28)}$. これも，一種の発振現象といえる. パイプAからは, 常 に一定の流量であって, 水が供給されているにあかかわ らず, パイプ Bからの水の流れは, 断続的・周期的であ る. このととから, 発振が生じるためには, エネルギー や物質が流入・放出している, いわゆる “開放系”であ ることが，まず必要であることがわかる，さらに，(2) $\rightarrow$ (3) の過程でみられるように, 一度流れはじめる（反応し はじめる) と, その速度は減少せずに, 流れつづける(反 応しつづける）乙とが必要である.乙れを, 自己触媒的 過程（正のフィードバック）と呼ぶ. 次に, この自己触 媒的過程が, ある程度すすむと, 流れが（反応が）止ま るととが必要である(負のフィードバック). てのよう に, 一般に, 発振現象が生じるためには, 系が開放系で あって自己触媒的な過程と, そのフィードバック機構が 共に存在するてとが必須である.

\section{4. 油水界面での自励発振現象}

油水二層を接触させると, 界面がゆ行動く現象がある. これは, 界面を通しての物質移動に伴って生じる現象で あり, Marangoni効果と呼び, 化学工学の分野ではよ く知られている. Marangoni 効果は, 一般に界面活性 剤存在下では起こりにくい，ところが, 10 年余り前に,
フランス, キューリー研の Dupeyrat らは, 界面活性剂 存在下でむ, 界面がゆらぐ現象を見出した ${ }^{29,30)}$. 彼女ら は油水二層の界面張力の経時変化を測定し, それが, 減 衰型の振動（周期的変化）を示すととを報告している.

私達は,彼女らの実験系を改良することにより, 非減衰型 の発振の生じる条件を見出した ${ }^{311}$. Fig.4亿は，その実 験結果を示した. 油水二層接触後, 約 100 分ほどの誘導 期を経て, $\mathrm{pH}$ の振動が開始し, 乙れが 2 時間ほど持続 する.

電位の振動の機構としては, Fig. 5 で示したような, 界面での単分子層の形成・破壊の, 繰り返しが考えられ る. 当初, 水層では, CTAB ( hexadecyltrimethylammonium bromide) がミセルとして存在して抢り, 油層中には非解離型のピクリン酸 $(\mathrm{HA})$ がある. CTAB は, アルキル鎖が油層側へ配向し, 親水基が水層側に顔 を出した形で, 油水界面に移行しはじめる. それと同時 に，ピクリン酸が界面で $\mathrm{H}^{+}$を放出し，陰イオンの形で $\mathrm{CTA}^{+}$( hexadecyltrimethylammonium cation) と1 オン対を形成する (以上がStep I). 界面での $\mathrm{CTA}^{+}$と ピクリン酸陰イオンのイオン対濃度が上昇し, 単分子層 が次第にできていく(Step II). 単分子層の表面圧が, ある閾値に達すると, 逆ミセルとして, $\mathrm{CTA}^{+}$およびピ クリン酸陰イオンが油層中へ移行し, 界面での単分子層 が消失する (Step III)，そこで, Step Iが再び開始する.

このモデルを理論的に検討するために, 次のような現 象論的方程式を考える ${ }^{321}$.

$$
\begin{aligned}
& \frac{d x}{d t}=j_{x}-k_{x} x-\varepsilon_{x} y \\
& \frac{d y}{d t}=j_{y}+k_{y} y-\varepsilon_{y} z \\
& \frac{d z}{d t}=k_{z} x y+\frac{\gamma z^{\mathrm{n}}}{\theta+z^{\mathrm{n}}}-\beta z
\end{aligned}
$$

こてで， $x, y, z$ は，それぞれ, 界面近傍でのピクリン 


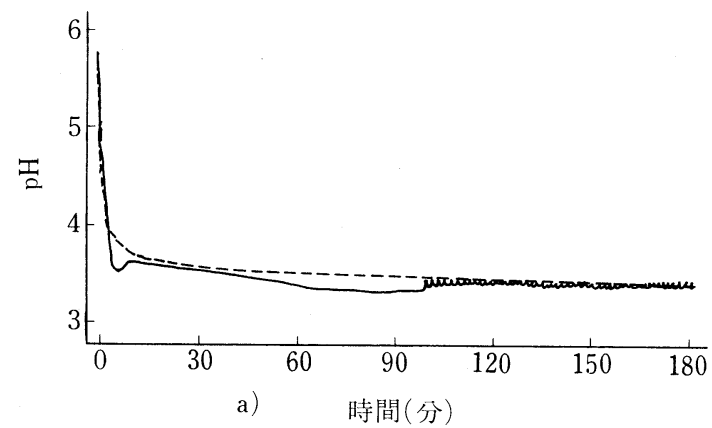

a) 油水二層接触後の水層側の $\mathrm{pH}$ 経時変化 実線は非擋拌時, 破線は擋拌時

油層； $1.25 \mathrm{mM}$ ピクリン酸を含む 2 -ニト ロプロパン

水層 ; $5 \mathrm{mM} \mathrm{CTAB}$ 水溶液

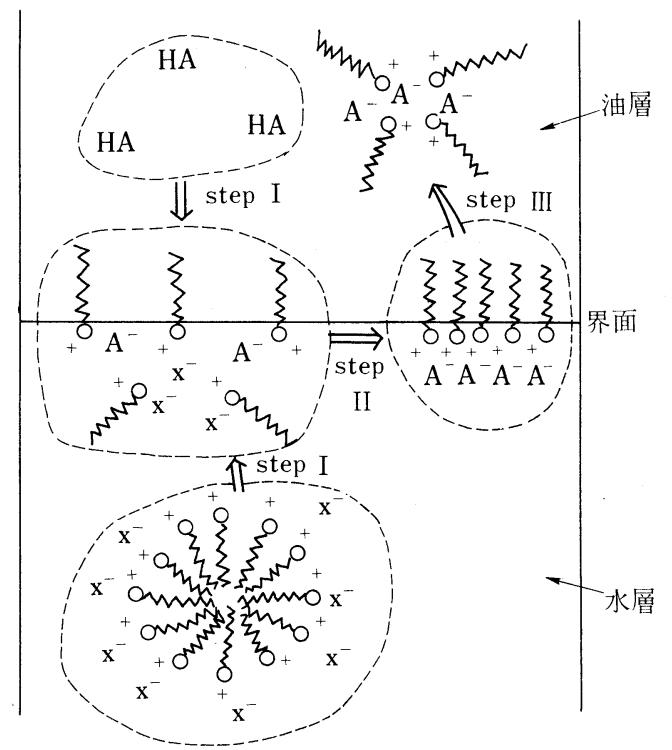

Fig. 5 油水界面での発振現象の機構

水層中の $\mathrm{CTAB}$ ミセルと, 油層中のピクリ ン酸 (HA)が, Step I, IIを通じて, 界面で 単分子層を形成し, Step III で一挙に油層側 へ逆ミセルとして移行する. そこで再び, Step I が開始する.

酸イオン, $\mathrm{CTA}^{+}$, および, ピクリン酸イオンと $\mathrm{CTA}^{+}$ のイオン対濃度を表わしている. $j_{x}, \quad k_{x}, \varepsilon_{x}, j_{y}, k_{y}$, $\varepsilon_{y}, k_{z}, \theta, \gamma, n, \beta$ は, パラメータである. (1) 式の第一 および第二項は，ピクリン酸イオンの油層から界面への 移動を示し, 第三項は, イオン対形成に伴うピクリン酸 イオンの減少を意味する. (2)式の第一, 二項は, $\mathrm{CTA}^{+}$ の水層から界面への移動を示し，第三項は，イオン対形 成に伴う $\mathrm{CTA}^{+}$濃度の減少を意味している. (3) 式の第一

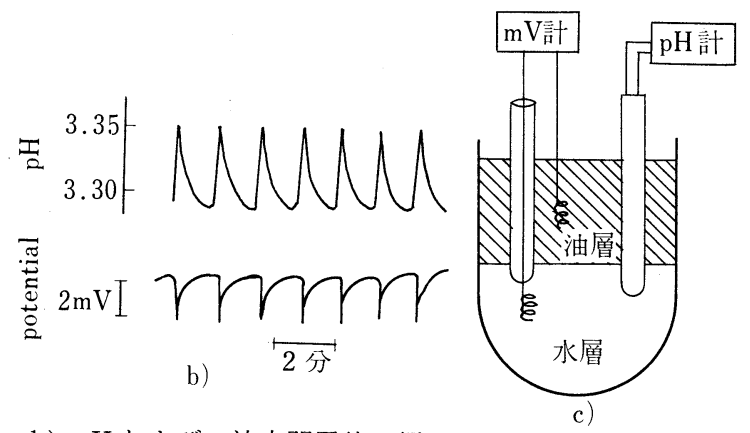

b) $\mathrm{pH}$ および, 油水間電位の経 時変化(拡大図)

c）実験装置
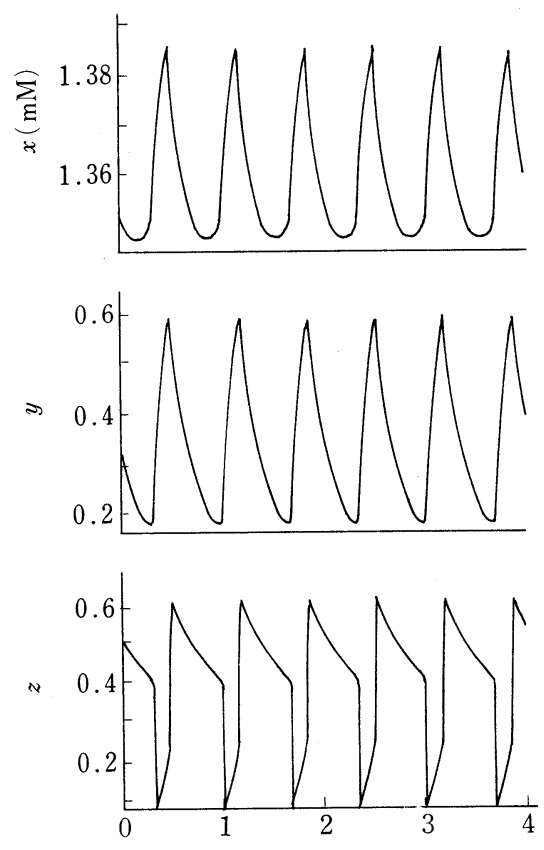

時間(分)

Fig. 6 現象論的非線形微分方程式(1)，(2),(3)を用い た計算機シュミレーション ${ }^{32)}$

$x, y, z$ は, それぞれ, ピクリン酸イオンと CTA+のイオン対濃度.

パラメータの值は, 次の通りである.

$j_{x}=j_{y}=3.33(\mathrm{mM} / \mathrm{min}), \varepsilon_{x}=1\left(\mathrm{~min}^{-1}\right)$,

$\varepsilon_{y}=10\left(\mathrm{~min}^{-1}\right), k_{x}=2.5\left(\mathrm{~min}^{-1}\right)$,

$k_{y}=1\left(\mathrm{~min}^{-1}\right), \quad k_{z}=150(1 / \mathrm{min} \cdot \mathrm{mM})$,

$r=190\left(\mathrm{~min}^{-1}\right), n=10, \theta=3^{-10}$,

$\beta=500\left(\mathrm{~min}^{-1}\right), x_{0}=3.0(\mathrm{mM})$ 
項は, イオン対の形成に関係し, 第二項は, 界面での単 分子層の形成過程が協同的（自己触媒的）であることを 意味する．第三項は，逆ミセルとしての油層への移行に 伴うイオン対濃度の減少である.

Fig. 6 には, (1)〜(3)式を用いた計算機シュミレーショ ンの結果を示した ${ }^{321}$ 。乙てで，乙れらの非線形連立微分 方程式が，振動解(リミットサイクル)をむつととに注意さ れたい，振動をひきおこすためには，単分子層形成時の $\mathrm{CTA}^{+}$同士の協同効果が，極めて重要であることが上の 式からあわかる.

以上のように, 油水二層系において, 定常的な発振の 生じることが，実験的にも，理論的にも確かめられた。 しかしながら，油水二層系での電位測定には，重大な問 題がある. すなわち二層系では真の層間電位を測定する ことは不可能であり, Fig. 4 で示した電位振動も, 層間 電位そのものを測定できているわけではない，そてで, 次に, 私達は, 実験系を改良し, 水-油-水三層加らなる 液体膜系についての研究を行った。

\section{5. 興奮性液体膜の化学物質に対す る特異的応答 (味覚類似機能)}

\section{$5 \cdot 1$ 実験装置・方法}

Fig. 7 亿実験装置の概略を示した。内径 $12 \mathrm{~mm}$ のガラ 又製U字管を用い, 水-油-水三層からなる液膜系をつく った。油層には, $1.5 \mathrm{mM}$ ピクリン酸を含むニトロベンゼン 溶液 $4 \mathrm{ml}$, 左側水層にはCTAB (hexadecyltrimethylammonium bromide) $5 \mathrm{mM}$ 水溶液を用い, 右あるいは 左側水層に各種化学物質を添加して左右水層間の電位変 化を計測した。乙の液膜系では，水-油-水三層接触後, 数分〜数十分後に $100 \sim 200 \mathrm{mV}$ 程度の規則的な電位振 動が生じる. この電位振動は，外部から電压・電流・水 圧など外圧が一切存在しない状態で発生することに注目 されたい.

\section{5 ・ 2 無機イオンに対する応答 ${ }^{33)}$}

Fig. 8 には, $\mathrm{KCl}$ 存在下の振動とリン酸イオン存在下 の振動を示した。このように，リン酸イオンが存在する と, 振幅が倍以上に増大し, 振動回数屯減少している. すなわち，乙のような CTABを用いた液膜では，陰イオ ンに対して特異的な応答を示す.
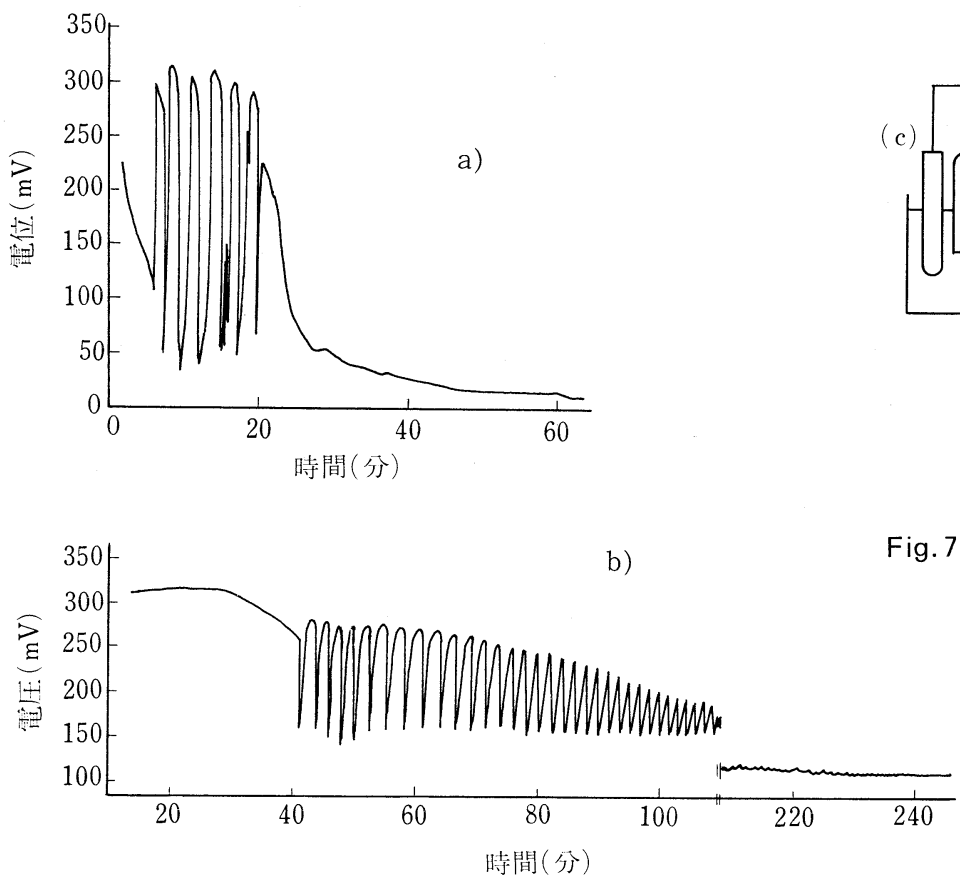

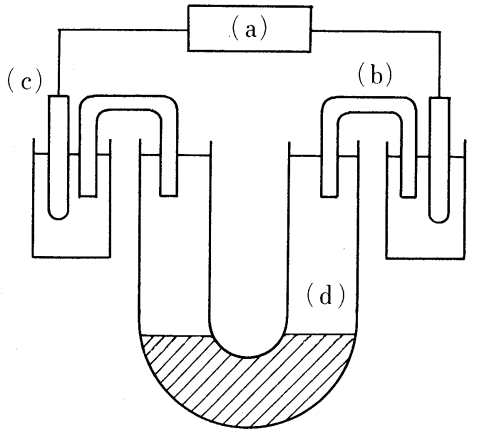

Fig. 7 興奮性液体膜実験装置

a) $\mathrm{mV}$ 計, b) $\mathrm{KCl}$ 塩橋

c) $\mathrm{Ag} / \mathrm{AgCl}$ 電極, d) U 字管

Fig. 8 右側水層に, a) $0.1 \mathrm{M}$ リン酸緩衝液 b) $3 \mathrm{M} \mathrm{KCl}$,を加えたときの電位振動 ${ }^{33}$ 


\section{5 ・ 3 アルコール類に対する応答 ${ }^{34)}$}

右側水層に $0.1 \mathrm{M}$ ショ糖, 左側水層に $5 \mathrm{mM} \mathrm{CTABを}$ 用い, さらに, 左側水層にエタノールを加えたときの電 位振動をFig.9に示した. エタノール濃度が増大するに 伴い, 振動の頻度も増えていることがわかる．同様な関 係は，他のアルキルアルコールを用いたときにもみられ た. 一般に, アルコール濃度を $C$, 振動の頻度を $f$ とす ると, 次の関係式 (4) が成立するととがわかった $(\mathrm{a}, \mathrm{b}$ は定数).

$$
\frac{C}{\log f}=\frac{C}{\mathrm{a}}+\frac{1}{\mathrm{~b}}
$$

Fig.10には,アルソールの鎖長を変えたときの, 濃度に 対する振動頻度の対数 $(\log f)$ の変化を示した. 各アルコ 一ルとも発振を引きおてすのに必要な閾值濃度があり, こ の閾値を越えると頻度 $f$ は急激に増大するが, ある頻度以 上にはならず, $f$ の増大は頭打ちになっていることがわか る. また, アルコール鎖が増大し, 疎水性が増えると, 閾値濃度が減少する傾向にあることが注目される.

そこで, Fig. 11 では縦軸に閾值濃度 $C_{\mathrm{th}}$ の対数を, 横軸にアルコールの疎水性をあらわすパラメータPの対 数をプロットしたものを示した. ここで $P$ は, 各アルコ
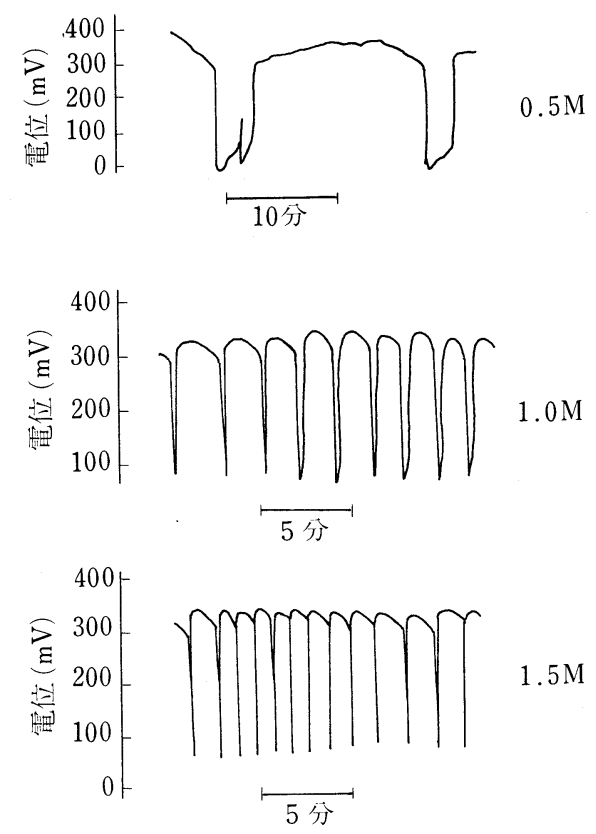

$1.5 \mathrm{M}$

Fig. 9 右左両水層間の電位の振動 ${ }^{34)}$

左側水層中のエタノール濃度を变化させたと きのもの, 図の右側にェタノール濃度を示し た
ールのベンゼン・水間の分配係数である.乙れより式(5) の関係が成り立っていることがわかる.

$$
\log C_{\mathrm{th}}=-\mathrm{a} \log P+\mathrm{b}
$$

$$
\text { ( } \mathrm{a}, \mathrm{b} \text { は定数) }
$$

これは, 薬物の構造活性相関を表わすHansch-Fujita の式 ${ }^{411}$ と同一である. 即ち, 各種の化学物質の生体式 に対する影響は, その薬物の疎水性と, 一般に, (5) 式で あって関係づけられることが判っている. こてで示した 興奮性の液体膜に対しても, 同一の関係式が得られたて とは興味深い。

アルコールとして, ベンジンアルコールを加えたとき には, 電位パルスが低 $\rightarrow$ 高電位側に発生した (Fig. 12). このことは, 電位振動の波形にも, 加えた物質の化学的 情報が反映していることを意味している。

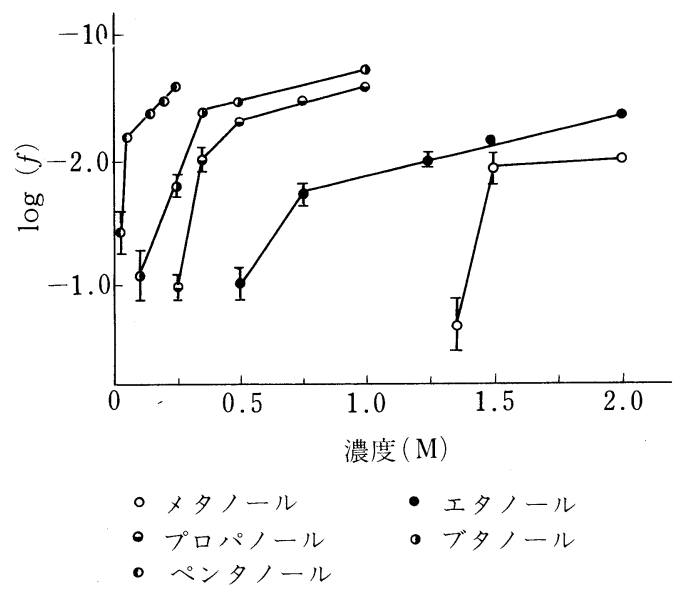

Fig.10 アルコールの濃度による, 振動頻度 $f$ (毎 分)の対数の変化 ${ }^{34}$

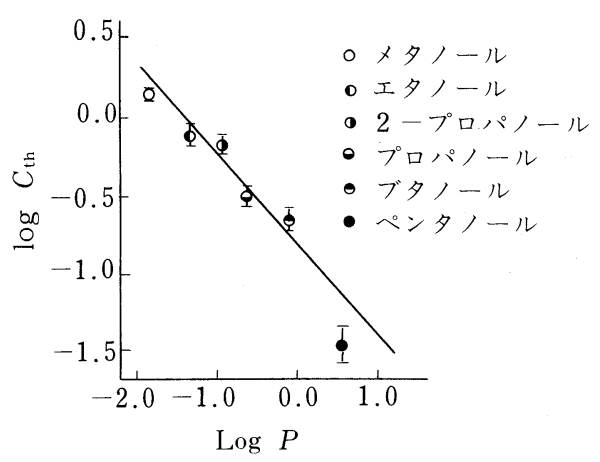

Fig.11振動を引きおこすアルコール濃度の闌値 $C_{\text {th }}$ とアルコールの疎水性 $P$ との関係 ${ }^{34)}$ ただし, Pは,ベンゼン・水間のアルコール の分配係数 


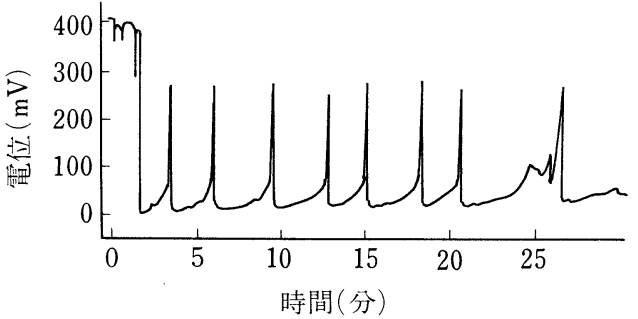

Fig.12 0.1Mベンジルアルコールを左側水層に加え たときの電位変動 ${ }^{34}$

\section{5 ・ 4 糖類に対する応答}

左側水層に $5 \mathrm{mM} \mathrm{CTAB}+1.5 \mathrm{M}$ エタノール水溶液を 入れ, 右側水層に, 各種糖類を加えたときの, 電位振動 を测定した. その結果, 振動パターンが加えた糖の構造 に依存し特異的に変化することがわかった．Fig.13には 横軸に $\log f(f$ は頻度 : 毎秒 $)$, 縦軸にパルスの数 $n$ を とったヒストグラムを示した，a）のようなヒストグラ ムは, ショ糖や各種へキソース $\mathrm{C}_{6} \mathrm{H}_{12} \mathrm{O}_{6}$ に拈いてみられ た。これに対し，b)のような分布の山が 2 つあるような ヒストグラムは, ヘキシット類 $\mathrm{C}_{6} \mathrm{H}_{14} \mathrm{O}_{6}$ についてみられ た。

\section{5 ・ 5 光学異性体に対する応答 ${ }^{35)}$}

光学活性な陽イオン性界面活性剤として, Nmethylbenzyl-N, N-dimethylmyristy ammonium bromideの, L, D 体を合成し, CTABの代わりに用い た. Fig.14は, 界面活性剤が L体のときのアラニンの D, L 体に対する電位応答である. 振幅が, $200 \mathrm{mV}$ 以上 のパルスについてのみ電位振動の頻度を調べてみると, D-アラニンで $1.8 \mathrm{~min}^{-1}, \mathrm{~L}-$ アラニンでは, $0.35 \mathrm{~min}^{-1}$ 之約 5 倍む振動数が異なる。すなおち, この液膜系は, 光学活性な化合物の chiralityを識別しているてとに なる.アラニン以外に，種々のアミノ酸や糖類について あ, 同様の実験を行ったところ, 同様にこの液膜の応答 性（振動頻度）は，L, D 体によって特徴的に変化する ことが判った.

\section{5 - 6 振動の振幅・周期・波形亡化学情報}

以上の実験結果をまとめたのが Fig. 15 である。乙の ように, この液膜系は, 電位変化の大きさ, 頻度, 波形 などにより, 種々の化学物質を認識することのできる, 全く新しいタイプの化学センサーとして発展させること のできる可能性のあることがわかる. 化学センサーとし て用いるためには，必ずしも，“自励発振”でなくても 良い。むしろ，測定したいときにだけ，外部電源と接続 し, 発振させる“他励発振”系の方が, 都合が良いとも a) ショ糖

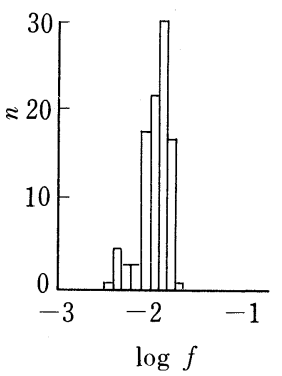

b) マンニトール

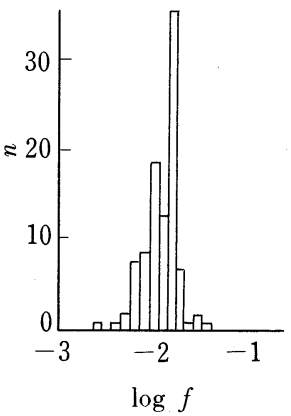

Fig. 13 糖に対する応答 頻度一パルス数ヒストグラム

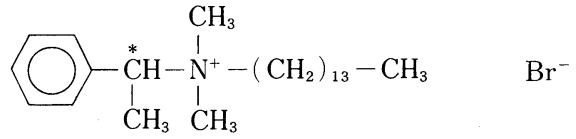

$\mathrm{N}-\alpha$-methylbenzyl-N, $\mathrm{N}$-dimethylmyristylammonium bromide

*は不斉炭素
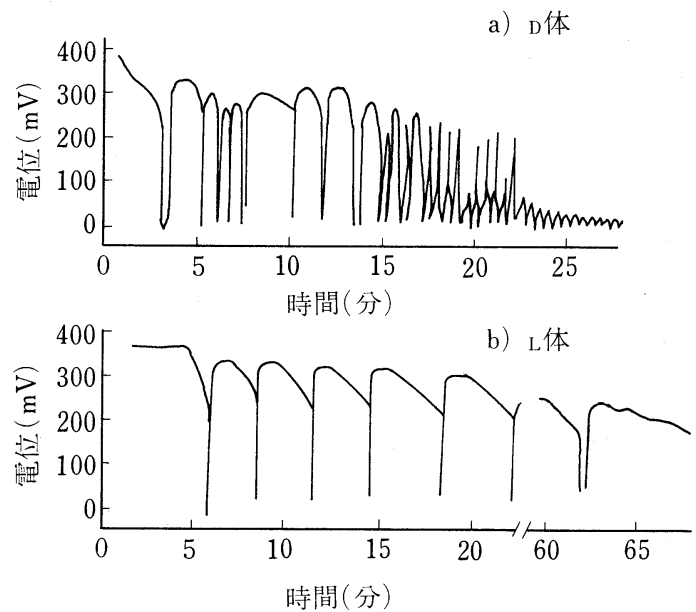

Fig.14 アラニンの光学異性体に対する応答 ${ }^{35)}$

言える.今後, “他励発振”系も含めて, 実験を進める 必要がある。

\section{6. アミン蒸気による液体膜の興奮 (嗅覚類似機能) ${ }^{36)}$}

次に, 二オイ物質に応答する, 興奮性の液体膜を作る ことを試みた. Fig. 16 亿実験装置の模式図を示した。 油層には，オレイン酸とプロパノールを $9 ： 1$ の割合で 混合し,さらに, $10 \mathrm{mM}$ の tetraphenylphosphoninm chlorideを加えたものを用いた。乙の脂溶性有機イオン 


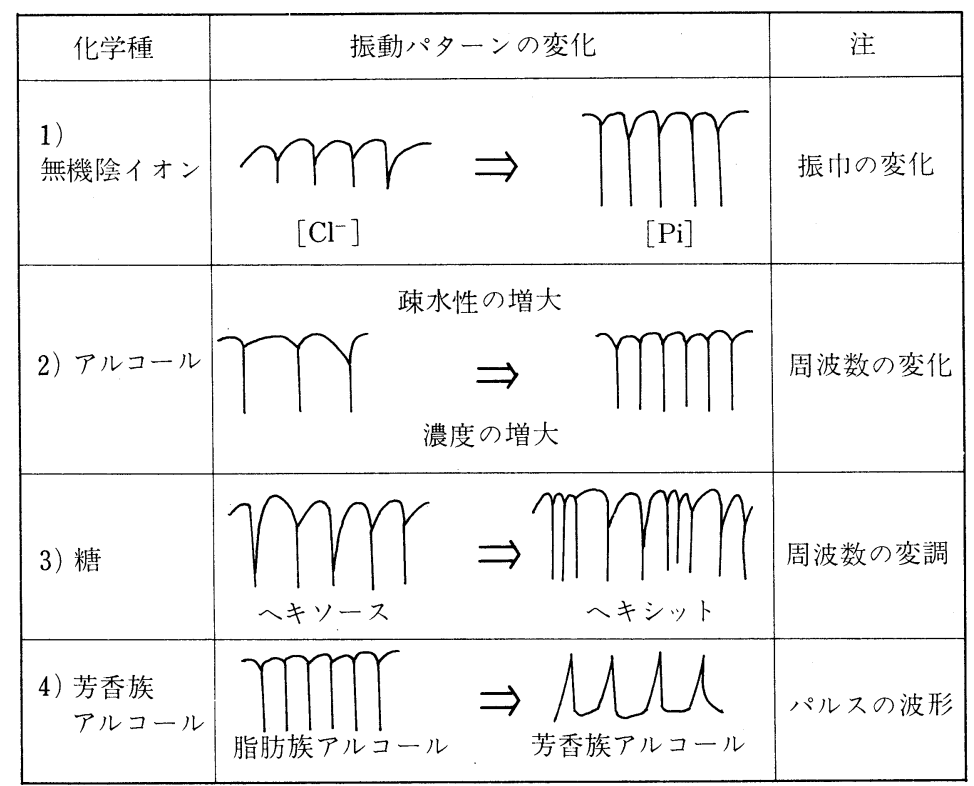

Fig.15 興奮性液体膜の, 種々の化学物質に対する電位応答
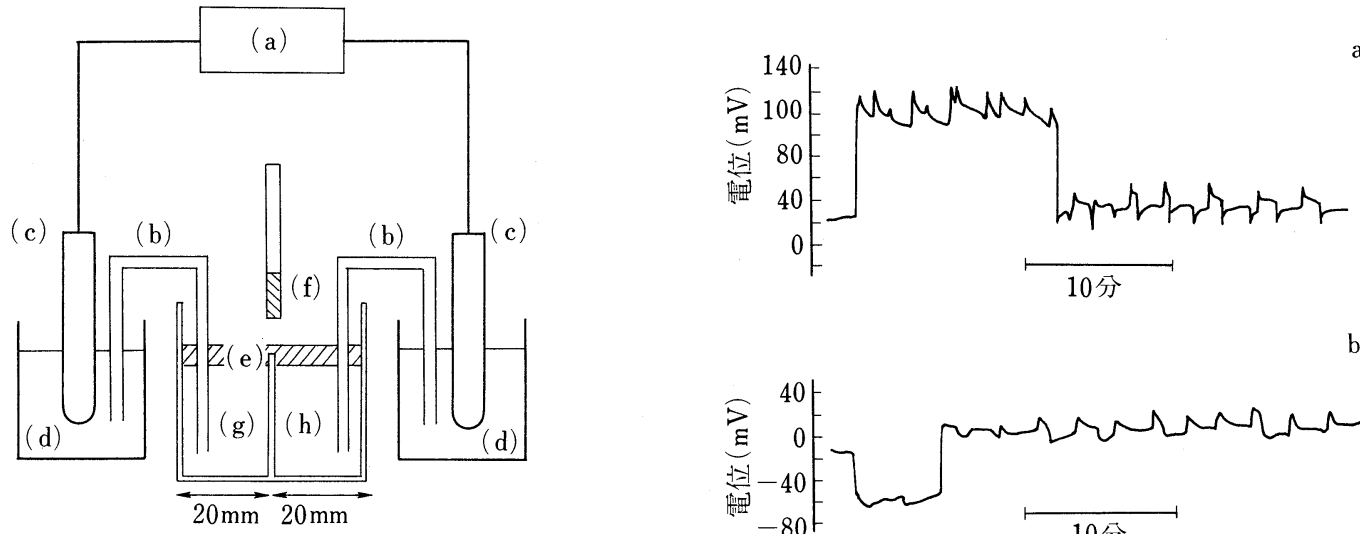

a)

b)

Fig. 16 オレイン酸油膜の実験装置 ${ }^{36)}$
a) $\mathrm{mV}$ 計
a) 塩橋
c) $\mathrm{Ag} / \mathrm{AgCl}$ 電極
d) $3 \mathrm{M} \mathrm{KCl}$
e) オレイン酸油膜
f）脱脂綿に浸み込ませたアミン
g) $0.5 \mathrm{M} \mathrm{NaCl}$ 水層
h) $0.5 \mathrm{M} \mathrm{KCl}$ 水層

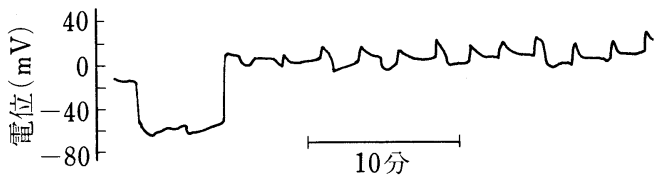

は, 油層の電気抵抗を減少させるために加えたものであ

り, このため, 両水相間の電位変化を精度良く測定する ことが可能となっている. Fig. 17 には，乙の液膜にアミ ン蒸気をふれさせたときの水相間の電位の経時変化を示 した，一応，周期性があるとみなせる電位応答をしてい

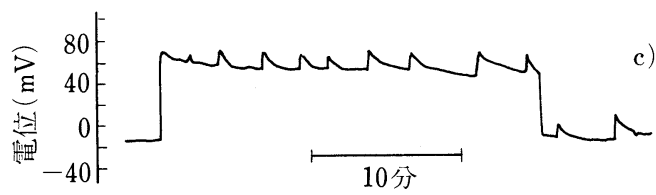
るてとがわかる，なお，時々生じている断続的な電位変 化は液面の自発的な動きによるものである.

Fig.17 オレイン酸油膜のアミン蒸気に対する電位 応答 ${ }^{36}$.
a) メチルアミン
b) ピリジン
c) ピペリジン 


\section{7. イオン濃度差によって駆動される 膜の興奮現象（神経類似機能）}

生体系に扔いて神経興奮現象が膜の外側, 内側の $\mathrm{Na}^{+}$\% $\mathrm{K}^{+}$イオン濃度差によって駆動されていることはよく知 られている．最近，私達は，一方に $\mathrm{NaCl}$ ，他方に $\mathrm{KCl}$ 水溶液を用いた人工膜系（テフロン，トリアセチルセル ロースからなるミリポアフィルターに，スパン-80, モノ オレイン等を含浸させた膜)に捛いて，なんら外部から電 流，電圧などの外力を加えることなく自発的かつ周期的 な振動を示すことを見出した ${ }^{37 \sim 39)}$. Fig. 18には，乙の ような膜における発振現象を模式的に示した ${ }^{399}$ 。従来, 生化学分野では膜の興奮現象には, チャンネルタンパク の存在が不可欠であると信じられてきた。 てれに対して, 我々の害験は脂質分子だけでも $\mathrm{Na}^{+} / \mathrm{K}^{+}$イオンの濃度差 により, 電気的興奮が発生するてとを示している.

Fig. 19 は, ミリポア膜の表面に, ジオレイルホルファ チジルコリン（リン脂質）からなる薄膜を貼りつけた膜 の自励発振現象である ${ }^{40)}$ 。乙こでは，水面上に展開した リン脂質の単分子膜をトリアセチルセルロース製のミリ ポア膜上に移し取ることにより, リン脂質薄膜を作製し た (Langmuir-Blodgett 法)。生体膜の主要な構成成分 であるリン脂質についてあ，乙のような発振現象がみら れることは興味深い。

Fig. 20 には, リン脂質の薄膜 ( LB 膜) の, 電流-電圧 特性を示した ${ }^{40)}$. 上の図の “非発振” 時の膜は, 左右両 水層の $\mathrm{KCl}, \mathrm{NaCl}$ 濃度が低いとき $(0.3 \mathrm{M})$ の屯のであ り, 下の図では, $0.5 \mathrm{M} \mathrm{KCl}, 0.5 \mathrm{M} \mathrm{NaCl}$ の両水層で

\begin{tabular}{|c|c|c|}
\hline 膜 & 振動パターン & 静止電位 \\
\hline $\begin{array}{l}\text { モノオレインま } \\
\text { たはスパンー80 } \\
\text { を含浸させたミ } \\
\text { リポア膜 }\end{array}$ & 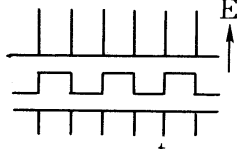 & \begin{tabular}{|r|l|l|} 
& & \\
& + & \\
$\mathrm{K}^{+}$ & + & \\
& + & \\
& + & $\mathrm{Na}^{+}$ \\
& + & - \\
\end{tabular} \\
\hline $\begin{array}{l}\text { トリオレインを } \\
\text { 今浸させたミリ } \\
\text { ポア膜 }\end{array}$ & & 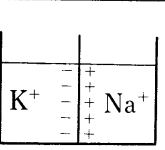 \\
\hline 神経膜 & 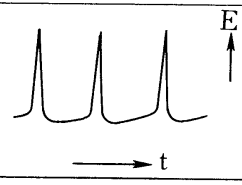 & $\mathrm{Na}^{+}$ \\
\hline
\end{tabular}

Fig. 18 ミリポア膜に脂質を含浸させて作製した膜 における自励発振と, 神経の興奮現象の対 比 ${ }^{39)}$
膜をはさんで測定している。上図で，スイッチングおよ び負性抵抗（電圧が上昇すると電流值が下る）の現象が みられる.さらに下図では, 電流值が $-0.18 \sim 0.15 \mu \mathrm{A}$ の領域で電位の発振が生じているてとがわかる。乙のよ うに，リン脂質薄膜だけで，スイッチング・負性抵抗， さらには記憶素子としての機能を発現することが可能で ある。

電位の自発的振動（自励発振）は高分子膜についても 生じる. Fig. 21 は，オレイル基を側鎖にもつ高分子より 製膜したものの，発振現象である ${ }^{41}$. flip-flop 型の電 位変化がみられる.

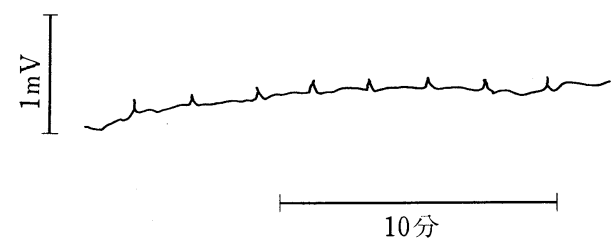

Fig. 19 リン脂質薄膜 (LB 膜) に打ける自励発振 40) 膜の左, 右水層として, $0.5 \mathrm{M} \mathrm{NaCl}, 0.5 \mathrm{M}$ $\mathrm{KCl}$ を用いた。
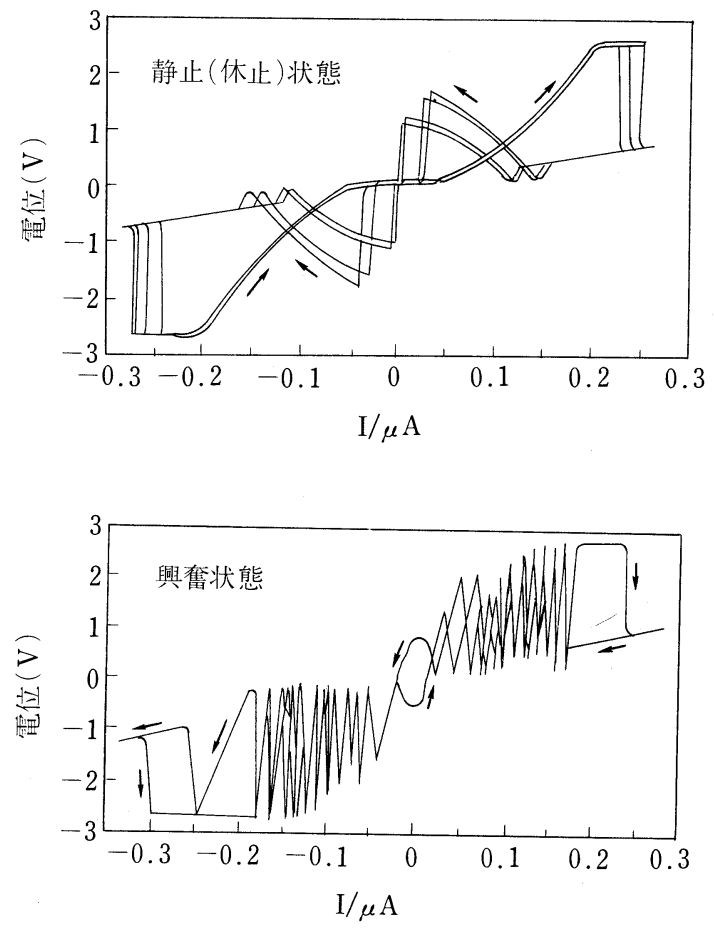

Fig. 20 リン脂質薄膜 (LB 膜)をはりつけたミリポ ア膜の電流一電圧特性 (電流制御) $\left.{ }^{40}\right)$ 上図は非発振時, 下図は発振時の特性 


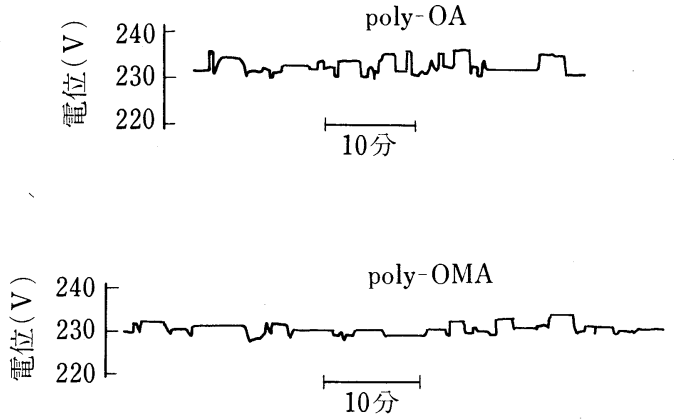

Fig. 21 高分子膜に拈ける電位の自励発振 41 ) 上図は, poly-OA (oleylacrylate), 下図 は, poly-OMA (oleylmethacrylate)膜, キャスト法により製膜. 左右両水層には, $0.5 \mathrm{M} \mathrm{KCl}$ および $0.5 \mathrm{M} \mathrm{NaCl}$ を用いた。

\section{8. おわりに}

以上，外部から電圧・電流・水圧などの外力をかける ことなく, 自発的に発振することのできる人工膜系につ いての研究結果を示した. 第 2 節ですでに述べたように 外力をかけたときに発振する膜系は，乙れ以外にも，い くつかのものが見出されてきている. センサーとしての 目的のためであるならば，むしろ，測定したい時にのみ 発振する膜系の方が都合が良い. そこで今後, そのよう な強制発振系む含めて, 研究を発展させなければならな い. Fig. 22 には, 興奮性の人工膜を, 情報変換素子とし たときの, 各種の外的刺激を認識するシステムの模式図 を示した．現在では未だ夢物語に過ぎないが, 将来的に, このような全く新しい型の情報変換・認知システムがで きても良いのではと考えている.

従来, 物理化学的測定や電気的計測のためには, でき るだけ“線形”に応答する系を選び, 専ら直線的に変化 する量についてのみ解析が行われてきた.しかしながら, 自然界に存在する系は, 生物, 無生物を問わず, 一般に “非線形”であり，“線形”な系は，むしろ特殊である. 今後, このような“非線形現象”を積極的にとりあげて, 研究を進める必要がある. 生物は本質的に, “非線形” な系と見なすととができるので，乙のような“非線形” な系の研究は, 生命現象の本質的な理解にもつながって いくはずである.

謝 辞 本稿で紹介した私共の研究は, 寺田助教授 (徳大薬), 太田教授, 高麗助教授(徳大工), 都甲博士 (九 大工), 石井助教授 (鶴見大), 入山助教授(慈恵医大), および, 徳大大学院生・学生の松原 (現京大化研), 尾持, 坂部之の共同研究である。乙れらの方々に謝意を表した い. 本研究の一部は, 文部省科学研究費执よび日産科学 振興財団の助成をうけて行った。
膜(MEMBRANE), Vol. 10, No.6 (1985)

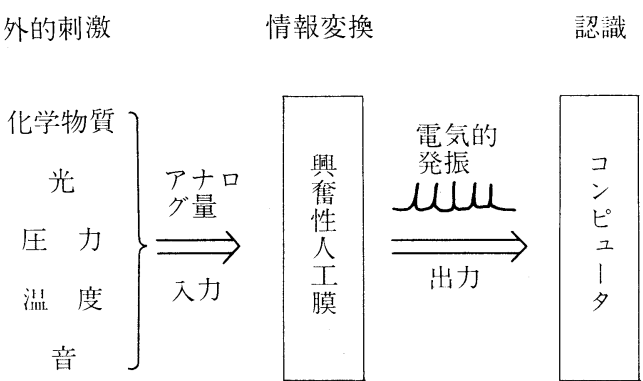

Fig. 22 新しい型の外部情報認知システム.

\section{引用文献}

1) 例えば, 栗原堅三: 科学, 54, 669 (1984).

2) H. Ogawa, M. Sato, S. Yamashita: J. Physiol., 199, 223 (1968).

3) T. Teorell: Z. Physik. Chem. Neue Folge, 15, 385 (1958).

4) T. Teorell: J. Gen. Physiol., 42, 831, 847 (1959).

5) U.F. Franck: Upsala J. Med. Sci., 85, 265 (1980).

6) P. Langer, K. R. Page, G, Wiedner: Biophys. J., 36, 93 (1981).

7) 山本啓太 : 科学, 31, 265 (1961).

8) M. Seno, T. Yamabe: Bull. Chem. Soc.Japan, 36, 877 (1963).

9) V.E. Shashoua: Nature, 215, 846 (1967).

10) V.E. Shashoua: Faraday Symp. Chem. Soc., 9, 174 (1974).

11) A. M. Monnier, A. Monnier : J. Physiol. (Paris), 56, 410 (1964).

12) A. M. Monnier, A. Monnier, H. Goudeau, A. M. Rebuffel-Reynier, J. Cell. Comp. Physiol., 66, 147 (1965).

13) A. M. Monnier: J. Membr. Sci., 2, 49, 67 (1977).

14) P. Mueller, D. O. Rudin: Nature, 213603 (1967).

15) P. Mueller, D. O.Rudin: Nature, 217, 713 (1968).

16) G. Boheim, W. Hanke, F. J. Barrantes, H. Eibl, B. Sakmann, G. Fels, A. Maelicke: Proc. Natl. Acad. Sci. USA, 78, 3586 (1981).

17) T. A. Last, M. L. Gantzer, C. D. Tyler: J. Biol. Chem., 258, 2399 (1983).

18) R. Coronado, R. Latorre: Biophys. J., 43, 231 (1983).

19) Y. Kobatake, A. Irimajiri, N. Matsumoto:Biophys. J., 10, 728 (1970).

20) Y. Kobatake: Adv. Chem. Phys., 29, 319(1975).

21) J. Arisawa, T. Furukawa: J. Membr. Sci., 2, 303 (1977). 
22) K. Toko, K. Ryu, S. Ezaki, K. Yamafuji: J. Phys. Soc. Japan, 51, 3398 (1982).

23) K. Toko, M. Tsukiji, S. Ezaki, K. Yamafuji : Biophys. Chem., 20, 39 (1984).

24) H. Pant, B. Rosenberg: Biochim. Biophys. Acta, 225, 379 (1971).

25) L. von Klitzing, M. Daber, H.-D. Bergeder : Biophysik, 9, 166 (1973).

26) V.F. Antonov, V. V. Petrov, A. A. Molnar, D . A. Predvoditelev, A. S. Ivanov: Nature, 283,585 (1980).

27）吉川研一, 早川俊美 : 化学の領域, 34, 612 (1980).

28) 吉川研一：現代化学, 10月号, 14 (1982).

29) M. Dupeyrat, E. Nakache: Bioelectrochem. Bioenerg., 5, 134 (1978).

30) E. Nakache, M. Dupeyrat, M. Vignes-Alder: Faraday Discuss. Chem. Soc., 77, 189(1984).

31) K. Yoshikawa, Y. Matsubara: J. Amer. Chem. Soc., 105, 5967 (1983).

32) K. Toko, K. Yoshikawa, M. Tsukiji, M. Nosaka, K. Yamafuji : Biophys. Chem., 22,151 (1985).

33) K. Yoshikawa, Y. Matsubara: Biophys. Chem., 17, 183 (1983).
34) K. Yoshikawa, Y. Matsubara: J. Amer. Chem. Soc., 106, 4423 (1984).

35) K. Yoshikawa, T. Omochi, Y. Matsubara, H. Kourai: J. Amer. Chem. Soc., in press

36) K. Yoshikawa, Y. Matsubara: Langmuir, 1, 230 (1985).

37) K. Yoshikawa, K. Sakabe, Y. Matsubara, T. Ota: Biophys. Chem., 20, 107 (1984).

38) K. Yoshikawa, K. Sakabe, Y. Matsubara, T. Ota: Biophys. Chem., 21, 33 (1985).

39) T. Ishii, Y. Kuroda, K. 'Yoshikawa, K. Sakabe, Y. Matsubara, K. Iriyama: Biochem. Biophys. Res. Commun., 123, 792 (1984).

40) K. Yoshikawa, T. Ishii, Y. Kuroda, K. Iriyama: 2nd International Conference on LangmuirBlodgett Films, Schenectady, New York, July 1-4 (1985); Biochem. Biophys. Res. Commun., in press.

41) K. Yoshikawa, T. Ohnishi, T. Omochi, T. Ota: Makromol. Chem., Rapid Commun., 6(1985), in press.

42) 構造活性相関㦝話会編: 薬物の構造活性相関, 化学 の領域増刊 122 号, 1 409, 南江堂 (1979).

\section{欧州膜学会主催 夏期学校（デンマーク）}

ESMST 主催のサマースクールが 1986年 6 月 2 日(月) から 6 日(金)まで，デンマークのAarhus で行われる。 内容は, Commercial Membranes ; Concentration polarization and fouling of membranes; Membrane modules; Dimensioning and operation of membrane plants; Commercial applications; New membrane processes であり, 招待講演を主とし, 少数
のポスターを受付ける．参加費は食費・宿泊費などを含 んでESMST 会員は 6,000DKr (約 \$600), 非会員は 6,500DKr である. 予備登録の 連絡先は Prof. G. Jonsson, Inst. for Kemiindustri, Technical Univ. of Denmark, DK-2800 Lyngby, DENMARK. な打1st Circularが事務局に来ていま すので関心のある方は申し出て下さい.

（事務局）

\section{第 2 回初代培養肝細胞研究会 お知らせ}

日 時：昭和 61 年 6 月 $5 \sim 6$ 日

場 所：徳島県鄉土文化会館（徳島市）

出席, 発表の詳細は右記に郵便にてお問い合わせ下さい.
初代培養肝細胞研究会 事務局

干 770 徳島市蔵本町 3 丁目 18 番地の 15

徳島大学医学部酵素研究施設 酵素病理部門

\section{第 8 回生体膜と薬物の相互作用シンポジゥム 予告（3）}

とき：昭和 60 年 11 月 11 日(月), 12 日(火)

ところ：岡山県総合福祉会館 (岡山市石関町 2-1 TEL (0862) $26-3501$

〔交通〕。岡山駅より路面電車 東山行「表町入

$$
\text { 口」下車徒歩 } 5 \text { 分 }
$$$$
\text { ○タクシー 約 } 10 \text { 分 }
$$

主 催：日本薬学会

協 賛:日本膜学会・他
プログラム

第 1 日（11月 11日）

A会場

$9: 30 \sim 12: 00$ 膜輸送（I）

IA-1 大腸菌メリビオース輸送系カチオン共役変異株に おりる輸送担体とカチオンの相互作用（岡山大・薬） 秋沢有四郎, 川上环磨，土屋友房 